наук : 13.00.02 / Егупова Марина Викоторовна Москва, 2014. - 452 с.

2. Кириченко Н. О. Роль элективных курсов в концепции предпрофильного и профильного обучения / Н. О. Кириченко // Наука и образование в современных условиях. Материалы Международной (заочной) научно-практической конференции. Под общей редакцией А. И. Вострецова. 2017. - С. 544-548.

3. Минина В. Ю. О готовности учителя к проведению и реализации элективных курсов / В. Ю. Минина // Теория и практика общественного развития. - 2013. - №1. - С. 140-143.

4. Минина В. Ю. Некоторые аспекты разработки модели формирования готовности будущего учителя к проектированию и реализации элективных курсов / В. Ю. Минина // Актуальные пробле- мы обучения математике Сборник научных трудов. Под ред. Ю. А. Дробышева. - Калуга, 2014. С. 116-124.

5. Лигай Л. В.

Организационнометодические условия формирования исследовательской деятельности студентов-будущих специалистов / Л.В.Лигай // Развитие и достижения в учебно-методическом обеспечении образовательной деятельности 69-ая региональная учебнометодическая конференция. - 2015. - С. 23-27.

6. Федяева Л. В. Элективные курсы философской направленности по математике как средство развития познавательного интереса учащихся классов математического профиля : дис. канд. пед. наук : 13.00 .02 / Федяева Людмила Викторовна Омск, 2013. - 236 с.

\title{
PSYCHOLOGICAL ASPECTS OF INTERACTIVE TEACHING METHODS INFLUENCE ON ENHANCING COGNITIVE ACTIVITY OF STUDENTS AT KAZAKH LANGUAGE LESSONS
}

\author{
Seitenova S.S. \\ c.p.s., associate. Professor, Head of the Chair of ARSU \\ named after K.Zhubanov, corresponding member of the Academy of CONCORD \\ c.Aktobe, Republic Kazakhstan \\ DOI: $10.31618 /$ ESU.2413-9335.2019.5.58.20-22
}

\section{ABSTRACT}

In the article psychological aspects of influence of interactive methods on activization of cognitive activity of students at training in teaching foreign language are considered. The concept of "interactive learning" is analyzed. The essence of interactive methods is studied as learning which is based on the psychology of human relationships and interactions of all students and teachers, where the processes of teaching and learning acquire a dynamic and open character.

Key words: interactive, methods, activation of cognitive activity, motivation.

The use of modern educational technologies in teaching is one of the most important and stable trends in the development of the world educational process. In the educational standards of general and secondary education of the Republic of Kazakhstan in recent years, various teaching technologies have become increasingly used in the study of most subjects. The level of development of teaching technologies, modern concepts of education, the need for students to develop the ability of continuous self-education throughout their life for adequacy of modern conditions makes it necessary to revise the technologies used in the educational process, choosing from them, first of all those that

- increase the effectiveness and quality of training; tivity;

- provide motives for independent cognitive ac-

- contribute to the deepening of the interdisciplinary connections through the integration of information and subject training.

Many students note indifference to knowledge, an unwillingness to learn, and a low level of development of cognitive interests. There is a polarization of students in terms of the level of mental and cognitive development, the formation of cognitive interests and initiative. Therefore, we believe that the main task of the educator in these conditions is to find more effective forms, models, methods and conditions for learn- ing. Thus, the problem of activization of students' activity in the process of education comes to the fore.

The activation of the cognitive activity of the trainees will correspond to the current requirements for the level of training of graduates of the university if an activity approach is taken in personal-oriented learning using interactive methods.

Interactive teaching is one of the modern directions of active social and psychological education. The analysis of theoretical literature led to the conclusion that interactive learning is a special form of organizing cognitive activity, in which all participants interact with each other, exchange information, jointly solve problems, simulate situations, evaluate the actions of others and their own behavior, immerse themselves in the real atmosphere of business cooperation to resolve the problem [1].

The essence of interactive methods is that learning is based on the psychology of human relationships and interactions and occurs in the interaction of all students and the teacher, and the processes of teaching and learning acquire a dynamic and open character. And, unlike active methods, interactive are oriented to a wider interaction of students not only and not so much with the teacher, but also with each other. All participants of the educational process exchange information, jointly solve problems, simulate situations [2]. At the same time the teacher's place in interactive classes ceases to be central, he does not give ready 
knowledge, but encourages trainees to independent search. As a result, when using interactive methods, practically every trainee is involved in the process of cognition, becomes a full participant in it, gets an opportunity to understand and reflect on what he knows and thinks. That is, the teaching is supplemented by training [3].

The main advantages of interactive forms of training are:

1. Activation of cognitive and intellectual activity of students.

2. Involving students in the learning process as active participants.

3. Development of skills of analysis and critical thinking.

4. Strengthening the motivation to learn the Kazakh language.

5. Creating a favorable climate in class. dents.

6.Development of communicative skills of stu-

7.Development of skills in possession of modern technical means.

8. Formation and development of skills of independent activity and information retrieval [4].

The application of interactive teaching methods allows to solve the following tasks:

- form an interest in the subject;

- develop the independence of trainees;

- enrich the social experience of trainees by experiencing life situations;

- feel comfortable in class;

- to manifest one's individuality in the educational process

When evaluating interactive learning outcomes, the following should be taken into account:

- work in a group;

self-assessment of the participant in the group work;

- Freedom of thought;

- Mastery of cultural forms of work;

- communication in the educational dialogue [5].

Basic methodical principles of interactive learning:

- careful selection of working terms, educational, professional vocabulary, conditional concepts;

- a comprehensive analysis of specific practical examples of managerial and professional activities, in which trainees perform various role functions;

- the maintenance by all trainees of continuous visual contact between themselves;

- active use of technical training tools, including slides, films, videos, video clips, interactive whiteboards, which illustrate the educational material;

- constant maintenance by the teacher of active intra-group interaction, removal of tension;

- operative intervention of the teacher in the course of the discussion in the event of unforeseen difficulties, and also in order to explain the new curriculum provisions for the students;

- Intensive use of individual classes (homework of a creative nature) and individual abilities in group classes;
- training in decision-making under conditions of strict regulations and the presence of an element of uncertainty of information [6].

Applying interactive forms and methods of teaching, we set ourselves a number of important educational goals:

- stimulate motivation and interest in learning the

Kazakh language;

- increase the level of activity and independence of students;

-develop skills of analysis, critical thinking, interaction, communication;

- changing attitudes towards cooperation and social values;

-development and development due to activation of intellectual activity and dialogical interaction with the teacher and other participants of the educational process [7].

At the moment, we can distinguish the following forms of interactive learning: heuristic conversation; creative task; discussion; business and role-playing games; training; round table; colloquium; "Brainstorming", the method of projects. A special place in this series is the method of projects. This means of modeling various conditions of professional activity by the method of searching for new ways of doing it.

Applying interactive methods of teaching in the classroom, we are trying to achieve new opportunities, first of all, by establishing interpersonal interaction through external dialogue in the process of mastering the educational material. Indeed, between the trainees in a group, certain interpersonal relationships inevitably arise, and on how they will, the success of their learning activity largely depends. Skillful organization of interaction of trainees on the basis of educational material becomes a powerful factor of increasing the effectiveness of educational activities in general. The use of interactive forms and methods of teaching contributes to the creation of success situations, which is a powerful stimulus for activating the cognitive activity of students in foreign language classes [8].

\section{List of used literature:}

1.Mukhina SA, Modern innovative technologies of training- M.: GEOTAR-Media, 2008. - $360 \mathrm{~s}$

2. Panina TS, Modern ways of activization of training: textbook - M .: Academy, 2008. - 176 p.

3. Dmitrieva EA, Application of interactive methods in the educational process [Electronic resource] / E.A. Dmitrieva, OA Tinyakov, E.N. Burdastykh // Uchenyezapiski: e-journal of the Kursk State University. Series of Pedagogical Sciences, 2014.- No. $1 \quad$ (29).- $\quad$ (http://www.scientificnotes.ru/pdf/034-029.pdf).

4. Nikishina IV, Interactive forms of methodical training. - M., 2007. - 150 p.

5. Polat ES, New pedagogical and information technologies in the education system. - M.: IC "Akademiya", 2002. c - 77 p.

6. Bespalko VP, Pedagogy and progressive learning technologies - M., 2001. - $80 \mathrm{p}$

7.Seitenova S.S. Mode of study of the Kazakh language in view of psychological factors. Life Sci J 


2014;11(6s):201-205] (ISSN:1097-8135). http:// Journal of Scientific Research Homep Issue 13 (
www. lifesciencesite.com. 38 Special Issue on Socio-Economic Sciences and

8. Seitenova S.S. Language Training with Professionally-Oriented Texts Журнал Middle East Humanities), Индекс Н : 2 212-217 б.

\section{ФИНАНСОВАЯ КУЛЬТУРА КАК РЕЗУЛЬТАТ ФИНАНСОВОГО ОБРАЗОВАНИЯ.}

\author{
Берзон Николай Иосифович, \\ доктор экономических наук, профессор, \\ руководитель Федерального методического иеетра по финансовой грамотности НИУ ВШЭ
}

Силина Светлана Николаевна доктор педагогических наук, профессор, руководитель методической группь Федерального методического центра по финансовой грамотности НИУ ВШЭ DOI: $10.31618 / E S U .2413-9335.2019 .5 .58 .22-34$

\section{АННОТАЦИЯ}

В статье осуществлена постановка проблемы формирования финансовой культуры как результата финансового образования. Проведен сопоставительный анализ базовых дефиниций: финансовая грамотность и финансовая культура. Определены закономерности необходимости повышения финансовой грамотности населения строены. Представлены первые результаты работы ФМЦ НИУ ВШЭ и созданной федеральной методической сети в области повышения квалификации педагогов по программе финансовой грамотности и проведения первой межрегиональной Олимпиады школьников НИУ ВШЭ «Высшая проба» профиль «Финансовая грамотность». Показана масштабность показателей реализуемого федерального Проекта по обучению различных категорий населения страны финансовой грамотности.

Приведен сравнительный анализ результатов PISA по проверке уровня финансовой грамотности учащийся школ и сложившихся на данный момент систем финансового образования в России и за рубежом. Изучены содержательные и технологические подходы к обучению финансовой грамотности школьников. Дано авторское определение понятия финансовая культура, представлена структура и методологическая основа развития системы финансового образования и формирования финансовой культуры в России.

В работе дан авторский посыл к будущим перспективам исследования методологической базы формирования финансовой культуры. И самой сложной перспективной исследовательской задачей является моделирование самой системы (базовых элементов, структур, образовательных технологий и их взаимосвязей) финансового образования и формирования финансовой культуры в обществе. Предпринята попытка определения проблемного поля педагогического исследования в области всеобщего финансового образования.

Ключевые слова: финансовая грамотность, финансовая культура, система финансового образования, формирование финансовой культуры населения, обучение педагогов, олимпиада школьников по финансовой грамотности.

В своей работе мы сделали попытку актуализации проблемы трансформации финансовой грамотности населения российского общества в финансовую культуру.

Актуализация данной проблемы, на наш взгляд, связана с поиском ответов на ряд важных и принципиальных вопросов:

- не достаточно высокий уровень финансовой грамотности и финансовой культуры населения (результаты исследований уровня финансовой грамотности населения);

-разночтение авторских подходов в понятийном поле (финансовая грамотность, финансовая культура, личностные компетенции, содержательные компоненты и элементы, уровни формирования финансовой грамотности и культуры, индикаторы и показатели их определения, методики, технологии финансового образования и его результаты);

-отсутствие обоснованной методологической основы концепции формирования финансовой культуры; -отсутствие целостной педагогической системы формирования финансовой культуры и финансового образования;

-необходимость эффективной реализации Стратегии повышения финансовой грамотности в РФ на 2017-2023 годы (от 25.09.2017 г.).

В современном российском и мировом сообществе проблема формирования финансовой культуры обуславливается стремительным ростом необходимости повышения финансовой грамотности населения. По данным НАФИ (Национального агентства финансовых исследований) $44 \%$ россиян испытывают потребность в повышении финансовой грамотности. [https://nafi.ru]

Поэтому на наш взгляд, стремительное развитие процесса повышения финансовой грамотности населения является закономерным, поскольку:

- происходит постоянное усложнение финансовых рынков;

- появление новых финансовых инструментов (криптовалюта, токены ICO);

- облегчается доступ населения на рынок финансовых услуг (электронный банкинг). 